\title{
WŁASNY POTENCJAŁ DOCHODOWY GMIN WIEJSKICH W POZNAŃSKIM OBSZARZE METROPOLITALNYM
}

\author{
Agnieszka Kozera \\ Katedra Finansów i Rachunkowości Uniwersytetu Przyrodniczego w Poznaniu \\ Kierownik Katedry: prof. dr hab. Michał Jerzak

\begin{abstract}
Słowa kluczowe: potencjał dochodowy, dochody własne, samodzielność finansowa, gminy wiejskie, obszar metropolitalny

Key words: income potential, own income, financial autonomy, rural communities, metropolitan area

S y n o p s i s. Analiza sytuacji dochodowej podmiotów sektora samorządowego na podstawie osiąganych dochodów o charakterze stabilnym, do których zalicza się większość źródeł dochodów własnych, pozwala określić długookresową zdolność tych podmiotów do finansowania realizowanych przez nie zadań. Własny potencjał dochodowy umożliwia bowiem podmiotom sektora samorządowego kreowanie własnej polityki finansowej w ramach istniejącego prawa. Jest on jednym z ważniejszych czynników stabilnego rozwoju lokalnego. Celem głównym artykułu jest ocena kształtowania się poziomu i struktury własnego potencjału dochodowego gmin wiejskich w Poznańskim Obszarze Metropolitalnym w latach 2004-2016. Badania empiryczne przeprowadzono na podstawie danych pochodzących z Banku Danych Lokalnych Głównego Urzędu Statystycznego. Wyniki badań wskazują, że własny potencjał dochodowy gmin wiejskich z POM był wysoki w relacji do pozostałych gmin wiejskich w województwie wielkopolskim.
\end{abstract}

\section{WSTEP}

Własny potencjał dochodowy gmin stanowi jeden z czynników pozwalających kreować stabilny rozwój lokalny. Zdaniem Teresy Lubińskiej z zespołem, kategoria własnego potencjału dochodowego obejmuje większość źródeł dochodów własnych jednostek samorządu terytorialnego (JST) o charakterze stabilnym, które zapewniają cykliczne, w bardzo wysokim stopniu przewidywalne wpływy do budżetu JST oraz nie wygasają po upływie krótkiego czasu [Lubińska i in. 2007]. Poziom dochodów własnych per capita, a także ich udział w dochodach ogółem należą jednocześnie do głównych wskaźników obrazujących samodzielność (autonomię) finansową JST [por. Heller 2006, Zawora 2010, Jastrzębska 2012, Surówka 2013, Głowicka-Wołoszyn, Wysocki 2014, Poniatowicz 2015]. Wśród ogółu samorządów gminnych znacznie niższy poziom własnego potencjału dochodowego $\mathrm{w}$ relacji do gmin miejskich i miejsko-wiejskich wyróżnia gminy wiejskie. W ostatnich latach, a zwłaszcza w warunkach integracji europejskiej, zmianie ulegały jednak funkcje pełnione przez gminy wiejskie, które determinują poziom i strukturę dochodów własnych gromadzonych przez podmioty sektora samorządowego [Miszczuk 2003]. Wiele z nich, zwłaszcza te położone 
w bliskiej odległości od głównych metropolii ${ }^{1}$, zmienia charakter pełnionych funkcji - z typowo rolniczych na rezydencjalno-usługowe [por. Kozera, Wysocki 2015, Rosner, Stanny 2016]. Znaczny wpływ na zmianę własnego potencjału dochodowego wielu gmin wiejskich ma zjawisko suburbanizacji, czyli przenoszenie się ludności z obszarów miejskich na podmiejskie. W wyniku tego zjawiska na obszarach podmiejskich następuje szybki wzrost liczby ludności oraz rozwój aktywności gospodarczej. W rezultacie własny potencjał dochodowy gmin wiejskich, będący pochodną liczby ludności oraz liczby przedsiębiorstw, jest wyższy w obszarach metropolitalnych ${ }^{2}$ niż w gminach wiejskich znajdujących się poza tymi obszarami. Z uwagi na znaczenie gmin wiejskich w Polsce, które stanowią największą zbiorowość ogółu samorządów gminnych (ponad 60\%) i zajmują ponad 90\% powierzchni kraju [Bank Danych Lokalnych, dostęp: 04.05.2017], analiza sytuacji finansowej tych podmiotów, ze szczególnym uwzględnieniem źródeł ich finansowania (jakim są np. dochody własne), należy do ważnych z ekonomicznego i społecznego punktu widzenia zagadnień badawczych. Niewystarczający poziom dochodów własnych stanowić może barierę między innymi dla pozyskania środków zewnętrznych, zarówno o charakterze bezzwrotnym (m.in. z funduszy Unii Europejskiej) oraz zwrotnym, które determinują zakres inwestycji gminnych.

Celem głównym artykułu jest ocena kształtowania się poziomu i struktury własnego potencjału dochodowego gmin wiejskich w Poznańskim Obszarze Metropolitalnym (POM) w latach 2004-2016. POM składa się łącznie z 22 gmin z powiatu poznańskiego, a także obejmuje gminy Oborniki, Skoki, Szamotuły i Śrem [Statystyczne vademecum samorządowca, dostęp: 04.07.2017]. Wśród gmin wchodzących w skład POM siedem z nich należy do gmin wiejskich, tj. gminy Czerwonak, Dopiewo, Kleszczewo, Komorniki, Rokietnica, Suchy Las oraz Tarnowo Podgórne.

Badania empiryczne przeprowadzono na podstawie baz danych Bank Danych Lokalnych Głównego Urzędu Statystycznego, które przetworzono z wykorzystaniem podstawowych metod statystyki opisowej (miar położenia i dynamiki zmian). W celu przeprowadzenia oceny kształtowania się poziomu własnego potencjału dochodowego badanych gmin wykorzystano także analizę wskaźnikową. Analizie poddano kształtowanie się m.in. wskaźników: poziom dochodów własnych per capita oraz udział dochodów własnych w dochodach ogółem gmin.

\section{WYNIKI BADAŃ EMPIRYCZNYCH}

Dochody własne gromadzone przez JST obrazują potencjał finansowy tych podmiotów. Zdecydowanie wyższy poziom własnego potencjału dochodowego w przeliczeniu na mieszkańca wyróżnia gminy miejskie, natomiast niższy gminy wiejskie. W 2016 roku najwyższy poziom dochodów własnych per capita w województwie wielkopolskim odno-

Metropolie w Polsce to największe miasta na prawach powiatu, które wyróżnia dualność realizowanych zadań. Realizują one wiele ważnych funkcji w sferze socjalnej, społecznej, infrastrukturalnej i gospodarczej. Przesądzają one o poziomie życia nie tylko ludności zamieszkującej miasto, ale także tzw. obszary metropolitalne. W celu wyodrębnienia metropolii bierze się pod uwagę najczęściej kryterium funkcjonalne, czyli zasięg oddziaływania miasta i funkcje wyższego rzędu pełnione na rzecz otaczających je regionów [por. Markowski, Marszał 2006, Ładysz 2009, Szmytke 2013]. W Polsce wyróżnia się zazwyczaj 12 metropolii, do których zalicza się Białystok, Bydgoszcz, Gdańsk, Katowice, Kraków, Lublin, Łódź, Poznań, Rzeszów, Szczecin, Warszawę oraz Wrocław [por. Unia Metropolii Polskich].

2 Obszary metropolitalne definiuje się jako teren otaczający wielkie miasto, wykazujący liczne wzajemne powiązania funkcjonalne z metropolią, przejmujący zarazem część jej funkcji (w tym mieszkaniowych, usługowych, infrastrukturalnych i przemysłowych) [Ładysz 2009]. 
towały gminy miejskie - 1896,7 zł, natomiast najniższy gminy wiejskie - 1407,8 zł (tab. 1.). Należy jednak zauważyć, że gminy wiejskie są silnie zróżnicowane w zakresie potencjału finansowego. Zróżnicowanie to jest widoczne pomiędzy gminami wiejskimi należącymi do POM a pozostałymi gminami wiejskimi spoza tego obszaru. Gminy wiejskie z POM wyróżnia na tle pozostałych gmin różnych typów wysoki przeciętny poziom własnego potencjału dochodowego. W 2016 roku dochody własne uzyskiwane przez gminy wiejskie z POM stanowiły bowiem przeciętnie 2655,7 zł per capita i były niemal dwukrotnie wyższe w relacji do dochodów uzyskiwanych przez gminy wiejskie spoza tego obszaru. Szczególnie wysoki poziom własnego potencjału finansowego wyróżniał zwłaszcza dwie gminy wiejskie - Suchy Las (5372,6 zł per capita) oraz Tarnowo Podgórne (5300,4 zł per capita w 2016 roku). Wysoki potencjał dochodowy gmin wiejskich z POM wynika z pełnionych przez nie funkcji. Gminy wiejskie, takie jak Suchy Las oraz Tarnowo Podgórne należące do POM i zlokalizowane bezpośrednio wokół miasta Poznań, zatraciły swój rolniczy charakter -i pełnią obecnie funkcje typowo rezydencjalno-usługowe [por. Kozera, Wysocki 2015].

Tabela 1. Poziom dochodów własnych gmin w województwie wielkopolskim w latach 2004-2016

\begin{tabular}{|c|c|c|c|c|c|c|c|c|}
\hline \multirow[t]{2}{*}{ Rodzaj gminy } & \multicolumn{7}{|c|}{ Wartość w roku w zł per capita } & \multirow{2}{*}{$\begin{array}{c}\text { Dynamika } \\
\text { Zmian } \\
2016 / 2004 \\
(2004=100)\end{array}$} \\
\hline & 2004 & 2006 & 2008 & 2010 & 2012 & 2014 & 2016 & \\
\hline Ogółem & 593,8 & 722,2 & 949,9 & 973,9 & 1210,3 & 1392,4 & 1515,0 & 255,1 \\
\hline Miejskie* & 857,4 & 1076 & 1421,2 & 1364,4 & 1597,8 & 1736,1 & 1896,7 & 221,2 \\
\hline Miejsko-wiejskie & 625,3 & 744,7 & 1028,6 & 1071,3 & 1220,5 & 1432,6 & 1524,7 & 243,9 \\
\hline Wiejskie, w tym: & 537,3 & 648,8 & 850,0 & 874,4 & 1119,5 & 1266,8 & 1407,8 & 262,0 \\
\hline $\begin{array}{l}\text { - gminy wiejskie } \\
\text { w POM }\end{array}$ & 1227,3 & 1591,4 & 2274,0 & 299,5 & 2413,0 & 2323,4 & 2655,7 & 216,4 \\
\hline $\begin{array}{l}\text { - gminy wiejskie } \\
\text { spoza POM }\end{array}$ & 511,8 & 631,2 & 826,7 & 861,0 & 1099,7 & 1222,3 & 1366,3 & 267,0 \\
\hline
\end{tabular}

* bez miast na prawach powiatu.

Źródło: opracowanie własne na podstawie danych Banku Danych Lokalnych, dostęp: 4.09.2017 r.

Przeprowadzone badania empiryczne wykazały, że w 2016 roku w relacji do 2004 roku poziom własnego potencjału dochodowego samorządów gminnych w województwie wielkopolskim wzrósł w najwyższym stopniu w gminach wiejskich. Dochody własne gmin wiejskich w badanym okresie wzrosły bowiem o $162 \%$, podczas gdy gmin miejskich o $121,2 \%$. Należy jednak zauważyć, że znacznie wyższy wzrost własnego potencjału dochodowego zaobserwowano wśród gmin wiejskich zlokalizowanych poza POM niż w gminach należących do tego obszaru (tab. 1.). Poziom własnego potencjału dochodowego gmin wiejskich uwarunkowany jest przez wiele różnych czynników. Wśród nich wyróżnia się uwarunkowania demograficzne i gospodarcze, ale także ważne są czynniki przestrzenne, a w szczególności dla gmin wiejskich - ich położenie w odniesieniu do dużych miast i dostępność komunikacyjna [por. Głowicka-Wołoszyn, Wysocki 2014]. Gminy wiejskie w POM wyróżnia jednak relatywnie wysokie zróżnicowanie w zakresie własnego potencjału dochodowego. Rozstęp oraz współczynnik zmienności dla poziomu dochodów własnych w zł per capita dla gmin wiejskich w badanym obszarze metropolitalnym wynosiły odpowiednio $2133 \mathrm{zł}$ per capita i 56\% w 2004 roku oraz 3317 zł per capita i 41\% w 2016 roku$^{3}$.

3 Obliczenia własne na podstawie danych Bank Danych Lokalnych, dostęp: 04.09.2017. 
Ważnym czynnikiem kształtującym potencjał finansowy JST, jak zauważyła m.in. Beata Filipiak, są dochody podatkowe [Filipiak 2016]. Wysokość oraz struktura wpływów fiskalnych zależy m.in. od charakteru pełnionych funkcji i położenia terytorialnego gminy. Największe znaczenie dochodów podatkowych, z punktu widzenia własnego potencjału dochodowego, spośród ogółu JST notuje się właśnie wśród samorządów gminnych. Podatki stanowią podstawową kategorię dochodów własnych realizowanych przez gminy wszystkich typów administracyjnych. Kategoria ta obejmuje między innymi dwie ważne grupy danin publicznych, tj. podatki lokalne oraz udziały we wpływach z podatków dochodowych od osób fizycznych i prawnych. W tabelach 2. i 3. przedstawiono kształtowanie się wysokości i udziałów wybranych kategorii podatków w dochodach własnych gmin w województwie wielkopolskim. Jak wynika z zaprezentowanych danych, dochody z tytułu udziałów w podatkach PIT stanowią znaczący czynnik własnego potencjału dochodowego gmin w ujęciu ilościowym. Dochody pochodzące z udziałów w podatku dochodowym od osób fizycznych stanowiących dochody budżetu państwa w przypadku gmin wiejskich w województwie wielkopolskim wynosiły bowiem 658,0 zł per capita i prawie 37\% ogółu dochodów własnych w 2016 roku. Gminy wiejskie zaliczane do POM ze względu na bardzo wysoki potencjał demograficzny i gospodarczy (zwłaszcza gminy Suchy Las, Tarnowo Podgórne, Komorniki i Rokietnica) wyróżniał zdecydowanie wyższy udział omawianej kategorii dochodów podatkowych w dochodach własnych w relacji do gmin wiejskich spoza tego obszaru. W przypadku gmin wiejskich z POM dochody z PIT wynosiły w 2016 roku przeciętnie 1384,7 zł per capita, stanowiąc ponad 41\% ogółu dochodów własnych, natomiast w przypadku pozostałych gmin wiejskich przeciętnie 517,2 zł per capita i 35\% ogółu dochodów własnych.

W badanym okresie zaobserwowano wzrost znaczenia omawianej grupy dochodów własnych w budżetach gmin wiejskich, a zwłaszcza gmin zlokalizowanych w bliskim sąsiedztwie Poznania. W 2016 roku w relacji do 2004 roku nastąpił bowiem wzrost udziału dochodów z PIT w dochodach własnych gmin wiejskich z POM aż o 13,8 p.p., przy przeciętnym wzroście dla ogółu gmin wiejskich w badanym województwie wynoszącym 10,7 p.p. Wzrost znaczenia dochodów $\mathrm{z}$ tytułu podatku dochodowego od osób fizycznych w dochodach własnych gmin wiejskich zlokalizowanych wokół Poznania wynikał z obserwowanego od kilku lat zjawiska suburbanizacji. Jak zauważyły m.in. Joanna Stanisławska oraz Romana Głowicka-Wołoszyn, zjawisko to przejawia się dynamicznymi przemianami demograficznymi, polegającymi nie tylko na migracji ludności miejskiej na obszary wiejskie, ale także wzrostem przyrostu naturalnego i zmianami zachodzącymi w strukturze wiekowej ludności [Stanisławska, Głowicka-Wołoszyn 2017]. Na tereny podmiejskie przenoszą się bowiem często młode rodziny.

Położenie gmin wiejskich, takich jak Suchy Las, Tarnowo Podgórne, Czerwonak, Kleszczewo, Komorniki, Rokietnica, Dopiewo w bezpośrednim sąsiedztwie miasta Poznań wiąże się z odmienną ich funkcjonalnością. W 2016 roku w relacji do 2004 roku w gminach wiejskich w województwie wielkopolskim liczba ludności zwiększyła się o 8,8\%, podczas gdy w gminach wiejskich z POM aż o 56,3\% [Bank Danych Lokalnych 2017]. Gminy wiejskie z POM wyróżnia więc wysoki potencjał demograficzny, kwantyfikowany gęstością zaludnienia, która w 2016 roku wynosiła ponad 200 osób na km² w takich gminach, jak Rokietnica $\left(205 \mathrm{os} . / \mathrm{km}^{2}\right)$, Dopiewo $\left(222 \mathrm{os} . / \mathrm{km}^{2}\right)$ i Tarnowo Podgórne $\left(250 \mathrm{os} . / \mathrm{km}^{2}\right)$, ponad 300 osób na $\mathrm{km}^{2} \mathrm{w}$ gminie Czerwonak (331 os. $/ \mathrm{km}^{2}$ ) oraz ponad 400 osób na km² W gminie Komorniki (405 os. $/ \mathrm{km}^{2}$ ), podczas gdy przeciętna gęstość zaludnienia w gminach wiejskich województwa wielkopolskiego stanowiła zaledwie 64 osoby na $\mathrm{km}^{2}$, natomiast średnia dla kraju to 56 osób na $\mathrm{km}^{2}$ [Bank Danych Lokalnych, 2017]. Wzrost potencjału demograficznego gmin wiejskich z POM wpłynął więc nie tylko na zmianę pełnionych przez 
nie funkcji, ale w rezultacie na znaczny wzrost poziomu uzyskiwanych dochodów z tytułu podatku dochodowego PIT i poziomu własnego potencjału dochodowego tych podmiotów.

Wśród podatków lokalnych w budżetach samorządów gminnych największe znaczenie mają dochody pochodzące z podatku od nieruchomości, który zgodnie z przepisami ustawy o podatkach i opłatach lokalnych dotyczy gruntów, budynków lub ich części oraz budowli lub ich części związanych z prowadzeniem działalności gospodarczej. Stawki omawianego podatku są zróżnicowane i zależą od rodzaju nieruchomości, a także sposobu jej użytkowania. Samorządy gminne mają uprawnienia do różnicowania stawek podatkowych i wprowadzania zwolnień. W wyniku tych działań mogą oddziaływać na rozwój lokalny poprzez przyciąganie inwestorów zewnętrznych, pobudzanie rozwoju przedsiębiorczości itp. Wydajność fiskalna podatku od nieruchomości zależy od struktury użytkowanych gruntów oraz budynków i ich części. Dochody z podatku od nieruchomości będą tym wyższe, im wyższy będzie udział gruntów przeznaczonych do prowadzenia działalności gospodarczej. W przypadku samorządów gminnych, w których znaczna część nieruchomości przeznaczona jest na cele inne niż działalność gospodarcza (np. cele mieszkaniowe), znaczenie fiskalne tego podatku jest dużo mniejsze. W 2016 roku wpływy z podatku od nieruchomości w gminach województwa wielkopolskiego stanowiły niemal 550 zł per capita i 30\% ogółu dochodów własnych. W gminach wiejskich poziom tych dochodów był relatywnie niższy i wynosił 533,6 zł per capita. Należy jednak zauważyć, że poziom uzyskiwanych dochodów z podatku od nieruchomości wśród gmin wiejskich był w wysokim stopniu zróżnicowany. Gminy wiejskie z POM uzyskiwały w 2016 roku przeciętnie 1089,2 zł per capita, podczas gdy gminy wiejskie spoza tego obszaru 426,0 zł per capita z podatku od nieruchomości.

Znaczna część gmin wiejskich spoza POM pełni głównie funkcje typowe dla obszarów wiejskich - rolnicze. W systemie obciążeń podatkowych rolnictwa niewielką rolę odgrywa m.in. podatek od nieruchomości, co wynika ze stosowania zwolnień budynków rolnych i ich części położonych na gruntach gospodarstw rolnych i służących wyłącznie działalności rolniczej z tego podatku. Analizując dynamikę wpływów z podatku od nieruchomości w gminach wiejskich w 2016 roku w relacji do 2004 roku, zauważyć można wzrost dochodów z omawianego podatku o 51,8\% w gminach wiejskich z POM oraz ich wzrost aż o 103,7\% w gminach wiejskich spoza omawianego obszaru (tab. 2., 3.). Należy jednak pamiętać, że wysokość wpływów z podatku od nieruchomości zależy od ustalonych w danym roku stawek maksymalnych omawianego podatku, ale w szczególności od decyzji rad gmin, które ustalają obowiązujące stawki na dany rok. Niewątpliwie najwyższa dynamika wzrostu znaczenia tej grupy dochodów w dochodach własnych gmin wiejskich wynika z silnego rozwoju funkcji rezydencjalnych na obszarach wiejskich (m.in. wskutek znacznej poprawy w ostatnich latach stanu infrastruktury technicznej i społecznej). Wraz z rozwojem funkcji rezydencjalnych na obszarach wiejskich i wzrostem potencjału demograficznego pojawiają się nowe potrzeby społeczności lokalnych, co stymuluje rozwój funkcji usługowych. W badanym okresie wśród gmin wiejskich z POM najwyższy wzrost poziomu uzyskiwanych dochodów z podatku od nieruchomości odnotowano w gminach Kleszczewo, Komorniki i Tarnowo Podgórne (ponaddwukrotny ich wzrost) (tab. 4.).

Ze względu na znaczny udział użytków rolnych w powierzchni ogółem gmin wiejskich (przeciętnie 70\%) w gospodarce budżetowej tych podmiotów szczególnie znaczenie ma podatek rolny, który jest płacony niezależnie od poziomu uzyskiwanych przychodów z gospodarstwa rolnego i zazwyczaj klasyfikowany do grupy podatków majątkowych [por. Chmielewska 2009]. Podatek rolny jest głównym obciążeniem podatkowym gospodarstw 


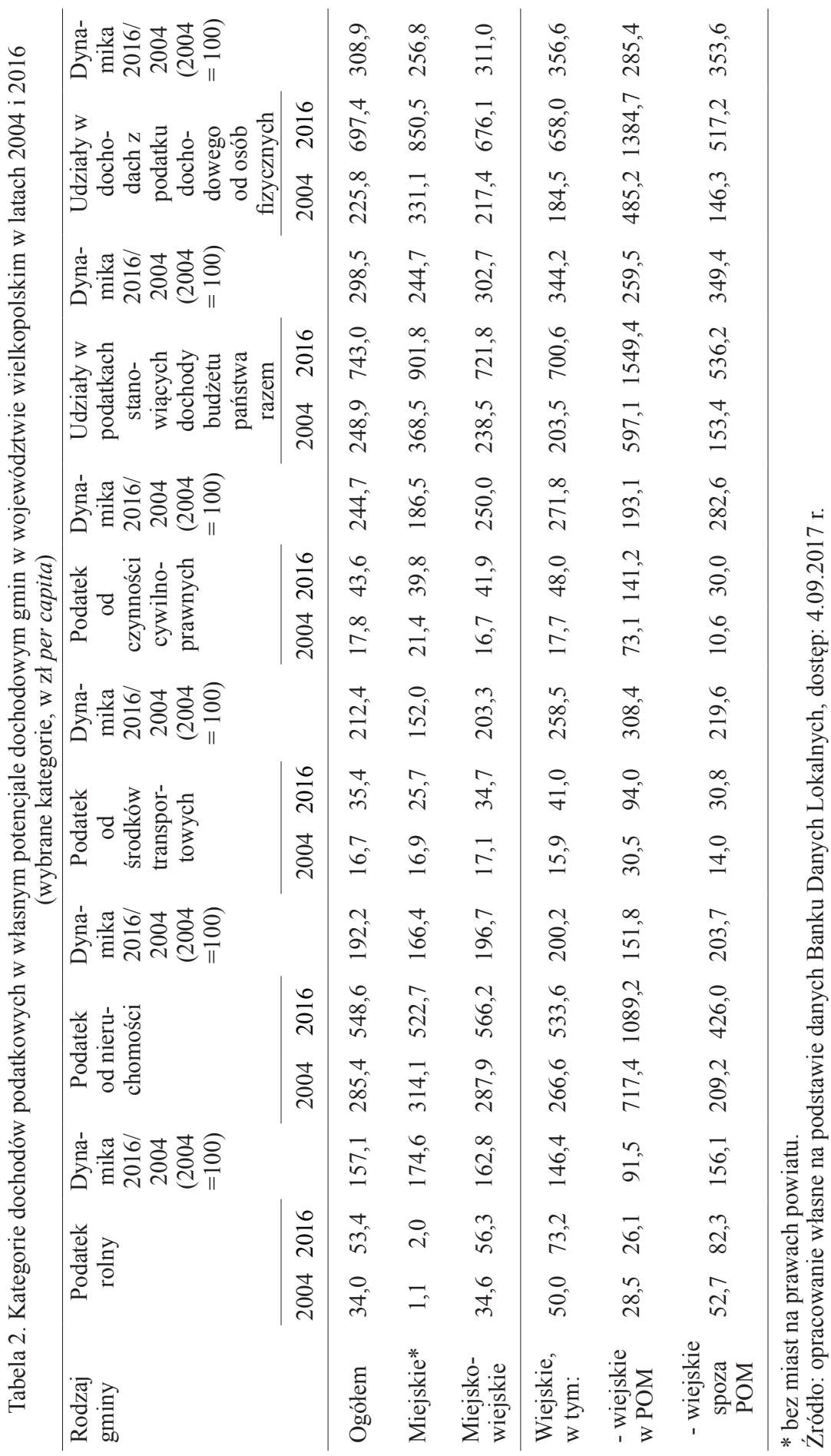




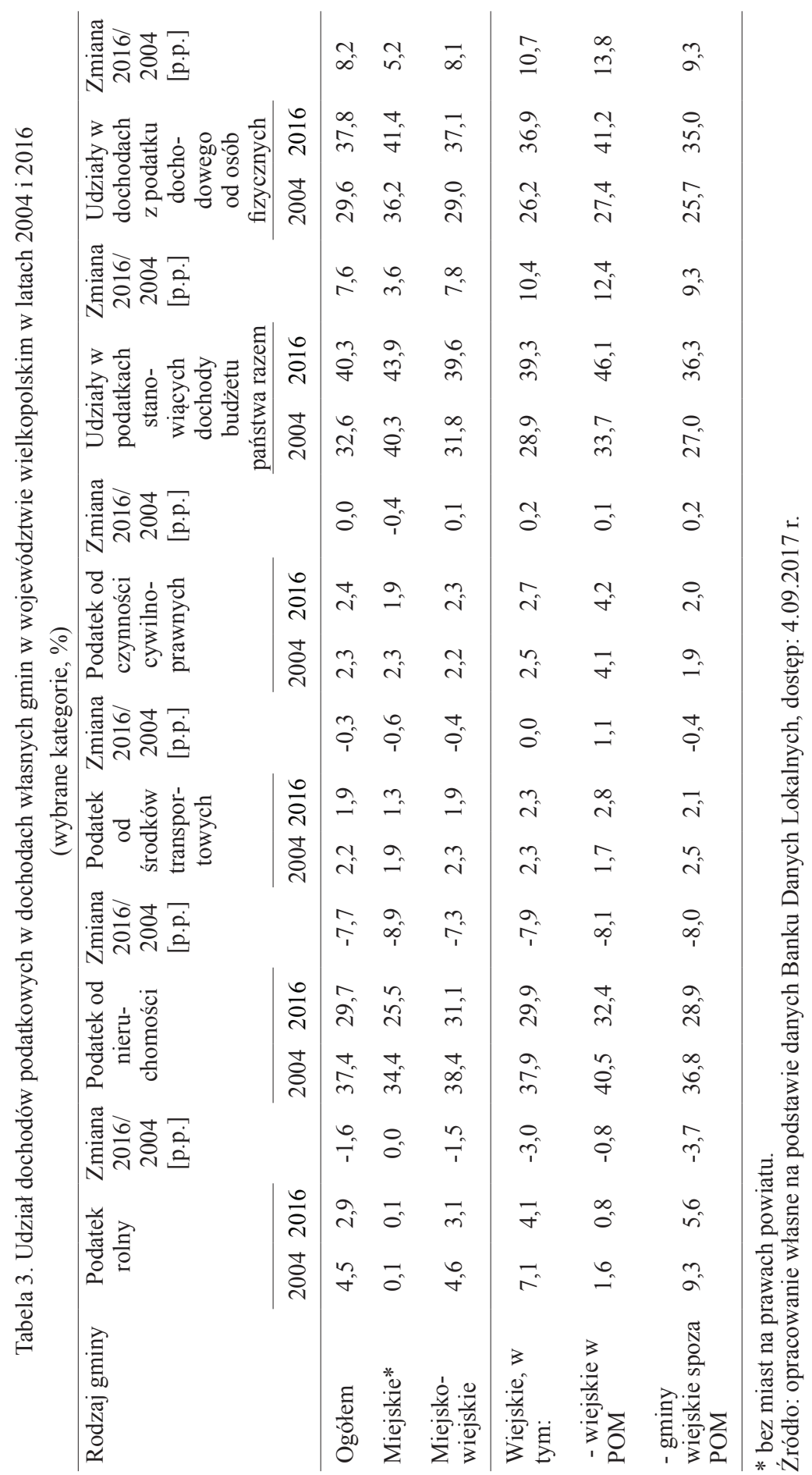




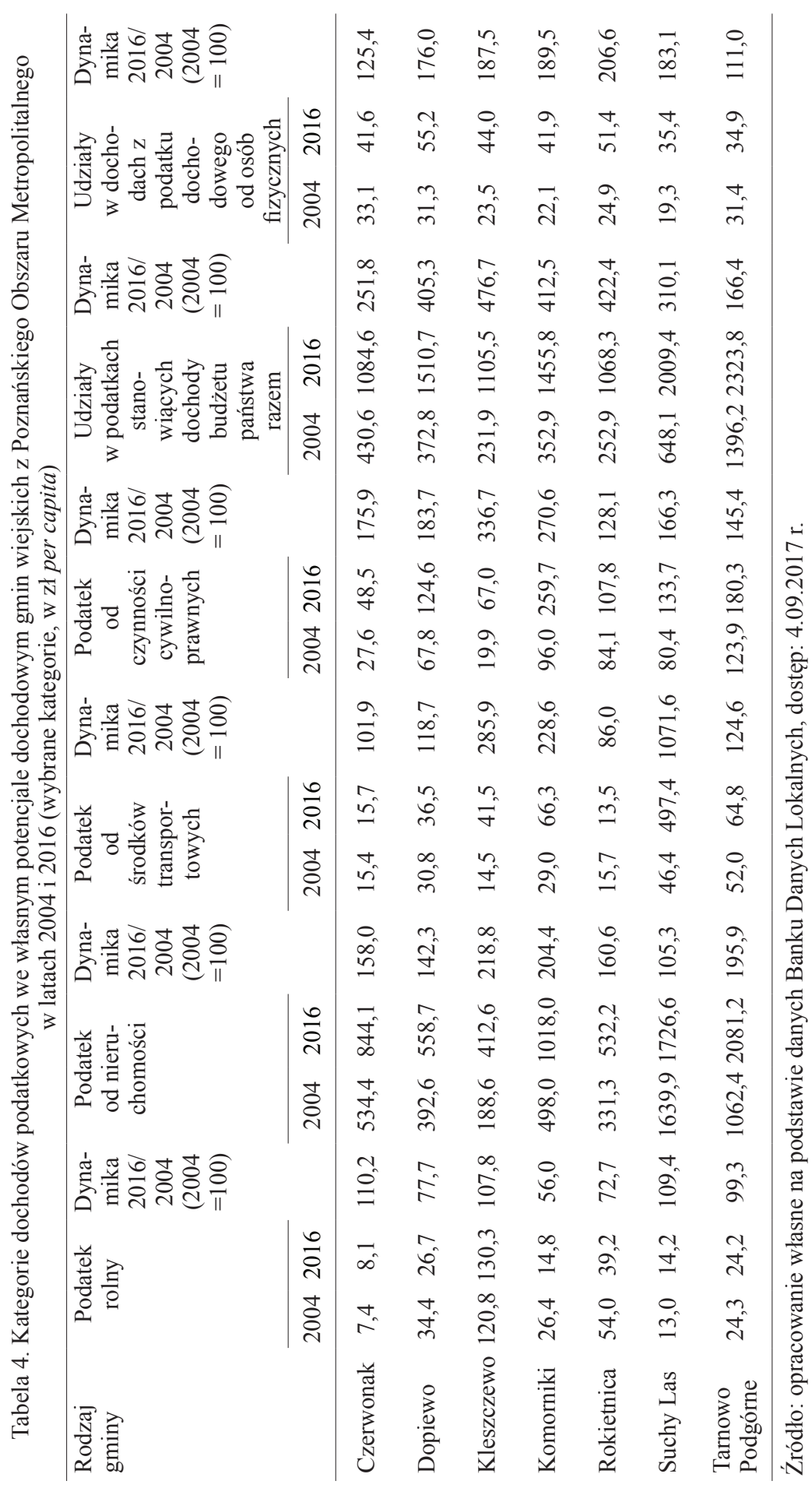


rolnych ${ }^{4}$ odprowadzanym do budżetów gmin, na których terenie położone są grunty podlegające opodatkowaniu. Dochody pochodzące z tego podatku w 2016 roku wynosiły przeciętnie 73,2 zł per capita $\mathrm{w}$ gminach wiejskich, podczas gdy w gminach miejsko-wiejskich 56,3 zł per capita (tab. 2.). Pomimo wzrostu poziomu dochodów pochodzących z omawianego podatku jego znaczenie w budżetach gmin wiejskich uległo zmniejszeniu. Sytuacja ta wynikała ze wzrostu w badanym okresie znaczenia dochodów własnych pochodzących z podatku dochodowego od osób fizycznych. W 2004 roku dochody z tytułu podatku rolnego stanowiły $7,1 \%$, natomiast w 2016 roku już tylko 4,1\% ogółu dochodów własnych gmin wiejskich w badanym województwie. Zmniejszenie znaczenia podatku rolnego jako źródła dochodów własnych samorządów gminnych zaobserwowano także w gminach wiejskich w POM (o 0,8 p.p.), ale w szczególności w gminach wiejskich spoza tego obszaru (o 3,7 p.p.) (tab. 3.). Wśród gmin wiejskich zlokalizowanych w POM to w gminie Kleszczewo dochody z podatku rolnego w przeliczeniu na mieszkańca kształtowały się na najwyższym poziomie, tj. 130,3 zł per capita $\mathrm{w} 2016$ roku. Znacznie niższy poziom takich dochodów zaobserwowano w gminie Rokietnica - 39,2 zł per capita w 2016 roku, natomiast bardzo niski jego poziom w gminach Suchy Las (14,2 zł per capita) i Dopiewo (8,1 zł per capita). Należy jednak zauważyć, że znaczenie podatku rolnego jako źródła dochodów własnych zmniejszyło się w badanym okresie we wszystkich gminach wiejskich z POM, ale w szczególności w gminie Kleszczewo (z 12,4\% w 2004 roku do 5,3\% w 2016 roku) (tab. 3., 5.). Podatek rolny jest mało efektywnym źródłem dochodów własnych gmin. Niska efektywność podatku rolnego z punktu widzenia poziomu samodzielności finansowej gmin wiąże się z przyjęciem za podstawę opodatkowania ceny jednego produktu rolnego, którego znaczenie w produkcji rolnej w Polsce sukcesywnie się zmniejsza ${ }^{5}$. Ponadto, jak wskazała Agnieszka Kozera, pomimo wzrostu dochodowości w polskim rolnictwie po wejściu Polski w struktury europejskie, nadal znaczna część gmin wiejskich stosuje niższe stawki podatkowe, które skutkują zmniejszeniem poziomu uzyskiwanych dochodów własnych. Przykładowo w 2015 roku utracone dochody z podatku rolnego w wyniku stosowania władztwa podatkowego stanowiły w gminach wiejskich w Polsce ponad jedną piątą ogółu dochodów z podatku rolnego [Kozera 2017].

Dochody pochodzące z pozostałych podatków lokalnych - od środków transportowych i czynności cywilno-prawnych mają w budżetach samorządów gminnych relatywnie niewielkie znaczenie. W województwie wielkopolskim dochody własne pochodzące z omawianych podatków lokalnych stanowiły w gminach ogółem 4,3\%, natomiast w gminach wiejskich 5,0\% ogółu dochodów własnych. Zdecydowanie wyższy poziom dochodów z tytułu podatków od środków transportowych i czynności cywilnoprawnych odnotowano w gminach wiejskich z POM. W 2016 roku dochody tych gmin z podatku od środków

$4 \quad$ Z badań przeprowadzonych przez Magdalenę Mądrą wynika bowiem, że podatek rolny stanowi ponad $80 \%$ ogółu obciążeń fiskalnych w gospodarstwach rolnych. Obciążenia te są jednak stosunkowo niewielkie w skali roku [Mądra 2009]. Z danych FADN wynika bowiem, że obciążenie podatkami dochodów z rodzinnego gospodarstwa rolnego w 2015 roku wynosiło niespełna 5,5\% [FADN, http://ec.europa.eu/agriculture/ rica/database, dostęp: 11.12.2017].

5 Podstawowe zasady opodatkowania rolnictwa podatkiem rolnym zostały opracowanie w 1984 roku i obowiązują w praktycznie niezmienionej postaci od 1985 roku. Stawka podatku rolnego jest wyznaczana na podstawie średniej ceny skupu żyta. Do 2013 roku ustalana była na podstawie pierwszych trzech kwartałów roku poprzedzającego rok podatkowy, natomiast od 2014 roku z 11 kwartałów poprzedzających kwartał poprzedzający rok podatkowy. Średnią cenę skupu żyta ogłasza corocznie Prezes Głównego Urzędu Statystycznego. W przypadku gospodarstw rolnych podatek rolny to równowartość 2,5 q żyta za każdy hektar przeliczeniowy, natomiast dla pozostałych użytków rolnych $5 \mathrm{q}$ żyta za każdy hektar przeliczeniowy [Ustawa z 16 listopada ... Dz.U. 2016.617, art. 6]. 


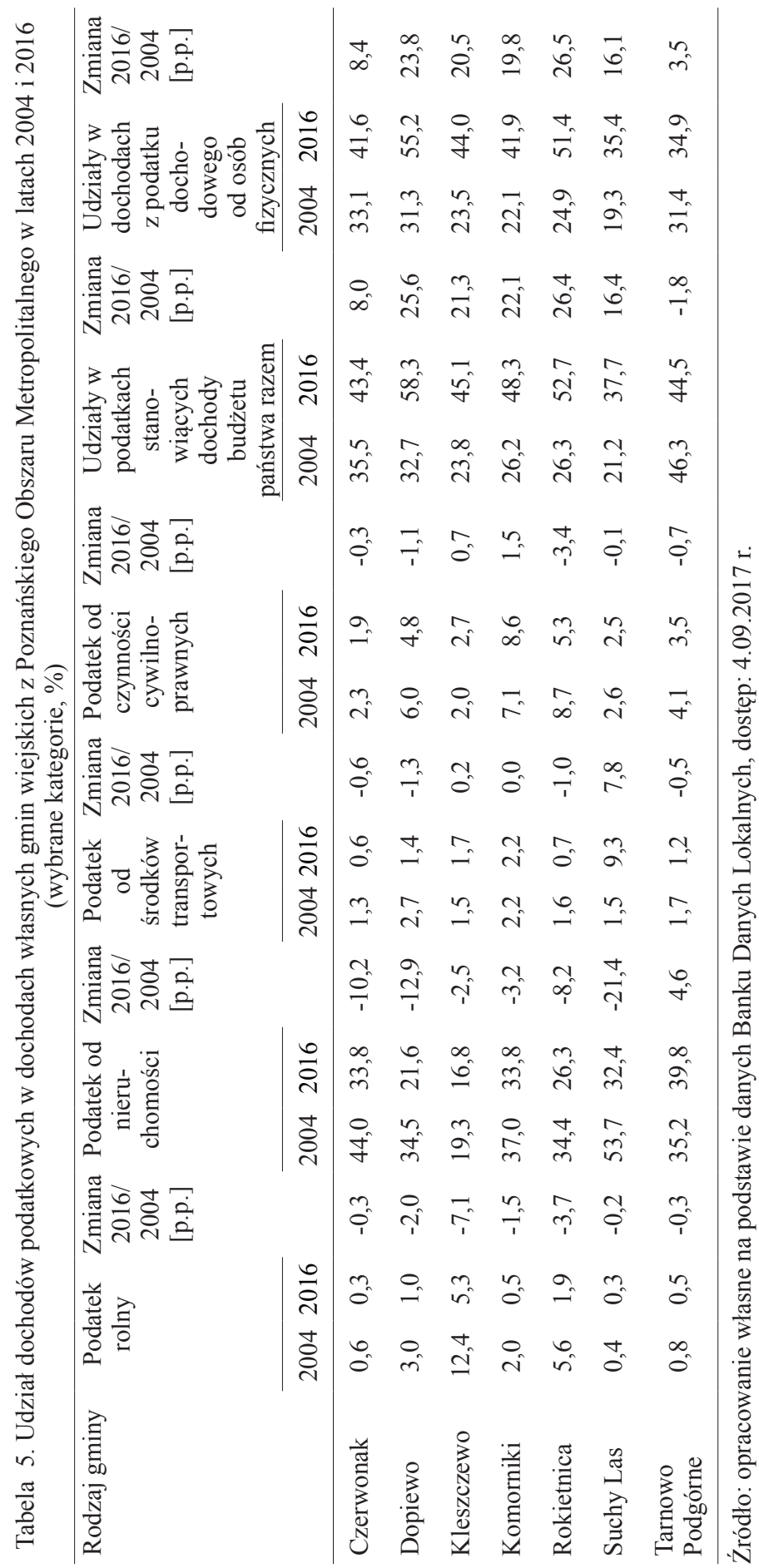


transportowych wynosiły bowiem 94,0 zł per capita i były ponadtrzykrotnie wyższe w relacji do dochodów uzyskiwanych przez gminy wiejskie spoza POM. Z kolei w przypadku dochodów pochodzących z podatku od czynności cywilnoprawnych dochody te $\mathrm{w}$ gminach wiejskich z POM wyniosły 141,2 zł per capita i były ponadczterokrotnie wyższe w relacji do dochodów uzyskiwanych przez pozostałe gminy wiejskie w badanym województwie (tab. 2.). Niewielkie znaczenie dochodów pochodzących z podatku od środków transportowych w budżetach samorządów gminnych wiąże się m.in. ze stosowaną przez gminy polityką podatkową. Z badań przeprowadzonych przez Jarosława Dziubę wynika, że najwyższą relację finansowych skutków stosowania instrumentów władztwa podatkowego do dochodów z tytułu podatków lokalnych notuje się właśnie w przypadku podatku od środków transportowych [Dziuba 2016]. W latach 2006-2014 utracone dochody w wyniku stosowania przez samorządy gminne obniżeń górnych stawek podatkowych, stosowania ulg i zwolnień, a także narzędzi ordynacji podatkowej stanowiły ponad 55\% uzyskanych dochodów z podatku od środków transportowych.

\section{PODSUMOWANIE I WNIOSKI}

Przeprowadzone badania empiryczne w zakresie kształtowania się poziomu i struktury własnego potencjału dochodowego gmin wiejskich w Poznańskim Obszarze Metropolitalnym w latach 2004-2016 wykazały, że:

- własny potencjał dochodowy gmin wiejskich w POM, kwantyfikowany wielkością dochodów własnych w przeliczeniu na mieszkańca, w porównaniu do gmin miejskich i miejsko-wiejskich był bardzo wysoki. W 2016 roku dochody własne gmin wiejskich z POM wynosiły przeciętnie 2655,7 zł per capita i były prawie dwukrotnie wyższe w relacji do dochodów własnych uzyskiwanych przez gminy wiejskie spoza tego obszaru;

- w 2016 roku w relacji do 2004 roku wyraźnie wzrósł poziom dochodów własnych gromadzonych przez gminy w województwie wielkopolskim, ale w szczególności najwyższa dynamika wzrostu własnego potencjału dochodowego wyróżniała gminy wiejskie; w badanym okresie dochody własne gmin wiejskich wzrosły o ponad $150 \%$, a dynamika wzrostu poziomu własnego potencjału dochodowego gmin wiejskich z POM była jednak niższa w relacji do jego zmian zaobserwowanych w gminach wiejskich spoza tego obszaru;

- własny potencjał dochodowy ogółu samorządów gminnych kształtowany jest głównie przez dochody pochodzące z podatków; najważniejszym źródłem dochodów własnych gmin wiejskich z POM są dochody pochodzące z udziałów w podatku dochodowym od osób fizycznych stanowiących dochody budżetu państwa, jak i dochody pochodzące z podatku od nieruchomości, które stanowiły w 2016 roku odpowiednio 46,1\% i 32,4\% ogółu dochodów własnych tych podmiotów;

- w wyniku obserwowanego od kilku lat zjawiska suburbanizacji i wzrostu potencjału demograficznego gmin wiejskich zlokalizowanych w bezpośrednim sąsiedztwie Poznania rosną dochody tych podmiotów pochodzące z podatku dochodowego od osób fizycznych. W 2004 roku stanowiły one 27,3\%, natomiast w 2016 roku aż 41,2\% ogółu dochodów własnych gmin wiejskich z POM.

Przeprowadzone badania empiryczne wykazały, że własny potencjał dochodowy gmin wiejskich z POM jest wysoki w relacji do pozostałych gmin wiejskich w województwie wielkopolskim. Na wyższy jego poziom wpływ mają korzystne (w wyniku obserwowanego 
zjawiska suburbanizacji) uwarunkowania demograficzne i gospodarcze, ale także bliskość Poznania i dostępność komunikacyjna. Gminy wiejskie zlokalizowane w POM pełnią w coraz większym zakresie funkcje rezydencjalne i usługowe, a przez to osiągają coraz wyższe wpływy do budżetu z tytułu podatków lokalnych oraz dochodowych stanowiących dochody budżetu państwa. Należy jednak zauważyć, że wraz z rozwojem tych funkcji pojawiają się coraz większe potrzeby społeczności lokalnych w zakresie infrastruktury technicznej i społecznej. Aby móc je zaspokoić i zapewnić jak najwyższy poziom życia, gminy wiejskie z POM, pomimo dobrej sytuacji dochodowej, podejmować powinny więc w sposób ciągły działania w celu wzmocnienia systemu dochodów własnych i prowadzić racjonalną gospodarkę budżetową.

\section{LITERATURA}

Bank Danych Lokalnych, Główny Urząd Statystyczny, Warszawa, www.stat.gov.pl/bdl.

Chmielewska Marzena, 2009: Podatek rolny w dochodach budżetowych gmin, „Zeszyty Naukowe SGGW w Warszawie. Ekonomika i Organizacja Gospodarki Żywnościowej”, nr 77, s. 187-197.

Dziuba Jarosław, 2016: Zróżnicowanie fiskalnych skutków polityki podatkowej jednostek samorząu terytorialnego, „Annales Universitatis Mariae Curie-Skłodowska, sectio H - Oeconomia”, vol. L, 1, s. 351-360.

FADN: http://ec.europa.eu/agriculture/rica/database, dostęp: 11.12.2017.

Filipiak Beata, 2016: Podatkowe czynniki ksztattujace potencjał finansowy jednostek samorzadu terytorialnego, „Finanse, Rynki Finansowe, Ubezpieczenia”, 1(79), s. 643-653.

Głowicka-Wołoszyn Romana, Feliks Wysocki, 2014: Uwarunkowania społeczno-ekonomiczne samodzielności finansowej gmin województwa wielkopolskiego, „Prace Naukowe Uniwersytetu Ekonomicznego we Wrocławiu", nr 346, s. 34-44.

Heller Janusz, 2006: Samodzielność finansowa samorząów terytorialnych w Polsce, „Studia Regionalne i Lokalne", 2 (24), s. 137-151.

Jastrzębska Maria, 2012: Finanse jednostek samorządu terytorialnego, Wolters Kluwer Polska Sp. z o.o., Warszawa.

Kozera Agnieszka, 2017: Podatek rolny jako źródto dochodów własnych gmin wiejskich w Polsce, „Roczniki Naukowe Ekonomii i Rozwoju Obszarów Wiejskich”, t. 104, z. 2, s. 76-86.

Kozera Agnieszka, Feliks Wysocki, 2015: Typ funkcjonalny a samodzielność finansowa gmin wiejskich województwa wielkopolskiego, ,Roczniki Naukowe Stowarzyszenia Ekonomistów Rolnictwa i Agrobiznesu", t. XVII, z. 6, s. 133-139.

Lubińska Teresa, Sławomir Franek, Marcin Będzieszak, 2007: Potencjał dochodowy samorzadu terytorialnego w Polsce na tle zmian ustawy o dochodach jednostek samorzadu terytorialnego, Difin, Warszawa.

Ładysz Iwona, 2009: Konkurencyjność obszarów metropolitalnych w Polsce na przykładzie Wrocławskiego Obszaru Metropolitalnego, Wydawnictwo CeDeWu.pl, Warszawa.

Markowski Tadeusz, Tadeusz Marszał, 2006: Metropolie, obszary metropolitalne, metropolizacja. Problemy i pojęcia podstawowe, Komitet Przestrzennego Zagospodarowania PAN, Warszawa.

Mądra Magdalena, 2009: Obciażenie podatkiem rolnym indywidualnych gospodarstw rolnych, „Zeszyty Naukowe SGGW w Warszawie. Ekonomika i Organizacja Gospodarki Żywnościowej”, 76, s. 175-186.

Miszczuk Magdalena, 2003: Czynniki różnicujace potencjał finansowy gmin jako przesłanka zmian systemu finansów lokalnych, [w] Lisiecki M. (red.): Zmiany jako czynnik rozwoju organizacji, Studia i materiały Instytutu Zarządzania i Marketingu Katolickiego Uniwersytetu Lubelskiego, tom 2.

Poniatowicz Marzanna, 2015: Determinanty autonomii dochodowej samorzadu terytorialnego w Polsce, „Nauki o Finansach”, 1(22), s. 11-30.

Rosner Andrzej, Stanny Monika, 2016: Monitoring rozwoju obszarów wiejskich - Etap II. Fundacja Europejski Fundusz Rozwoju Wsi i Rolnictwa, Instytut Rozwoju Wsi i Rolnictwa PAN, Warszawa. 
Stanisławska Joanna, Romana Głowicka-Wołoszyn, 2017: Przemiany demograficzne na obszarach wiejskich województwa wielkopolskiego w latach 2005-2015, „Roczniki Naukowe Stowarzyszenia Ekonomistów Rolnictwa i Agrobiznesu”, t. XIX, z. 1, s. 170-175.

Statystyczne Vademecum Samorzadowca, Główny Urząd Statystyczny, Warszawa, https://stat.gov. $\mathrm{pl}$ /statystyka-regionalna/statystyczne-vademecum-samorzadowca.

Surówka Krzysztof, 2013: Samodzielność finansowa samorzadu terytorialnego w Polsce, Polskie Wydawnictwo Ekonomiczne, Warszawa.

Szmytke Rober, 2013: W kwestii metropolii i obszarów metropolitalnych, „Przegląd Administracji Publicznej", nr 2, s. 35-47.

Unia Metropolii Polskich, http://www.metropolie.pl/pl.

Ustawa z dnia 12 stycznia 1991 r. o podatkach i opłatach lokalnych, Dz.U. 2016, poz. 716.

Ustawa z dnia 15 listopada 1984 r. o podatku rolnym, Dz.U. 2016, poz. 617.

Zawora Jolanta, 2010: Samodzielność finansowa samorzadów gminnych Podkarpacia, „Zeszyty Naukowe SGGW Ekonomika i Organizacja Gospodarki Żywnościowej”, 81, s. 137-145.

\section{Agnieszka Kozera}

\section{OWN INCOME POTENTIAL OF RURAL COMMUNES IN THE POZNAŃ METROPOLITAN AREA}

\section{Summary}

The analysis of the income situation of units of local self-government (entities of local government) based on achieved income, which include most of the sources of income of their own, can determine the long-term ability of these entities to finance their activities. Their own income potential allow local government units to create their own financial policy within the framework of existing law, so it is one of the important factors of sustainable local development. Among the communes, the lowest level of their own income potential distinguishes rural communes. However, these entities are highly diverse in this regard. With the socio-economic development, and especially after Poland's accession to European structures, the functions performed by rural communes (from the typical agricultural to residential and service functions), and especially those located in the vicinity of the largest cities, are changing. Change of functions performed by rural communities, especially those located in the so-called. Metropolitan areas, translates into a change in the level and structure of their own income of these entities. The main aim of the paper is to analyze the level and structure of own income potential of rural communities in the Poznan Metropolitan Area in the years 2004-2016. Empirical studies were conducted based on data from the Local Data Bank of the Central Statistical Office, which were processed using basic descriptive statistics methods.

Adres do korespondencji:

Dr Agnieszka Kozera

Wydział Ekonomiczno-Społeczny

Katedra Finansów i Rachunkowości ul. Wojska Polskiego 28, 60-637 Poznań e-mail: akozera@up.poznan.pl 